\title{
The Indonesian Government's Legal Policy on Mineral and Coal Sector
}

\author{
T. Saiful Bahri Johan \\ Faculty of Law \\ Jakarta Islamic University \\ Jakarta, Indonesia \\ mrhasan95@yahoo.com
}

\begin{abstract}
Legal Policy on mineral mining and coal has provided protection to the people and the nation as a form of state partiality to the nation's interests based on the constitution. The enactment of Law No. 4 of 2009 on Mineral and Coal Mining and Law No. 23 of 2014 on Regional Government greatly impact on the legal and economic sectors of society. In this case, on the one hand, it provides protection. On the other side, it can cause harm to society. This article is a conceptual idea that discusses the Indonesian Government's policy on mineral and coal mining management with the Policy of law analysis approach. The systematic discussion with the literature review of legal policy or analysis policy of law was supported with data in the field which was the result of previous research. From the analysis and the study, it showed that it needs to makethe meaning and reconstruction on policy of mineral mining and coal in comprehensively.
\end{abstract}

\section{Keywords - legal policy, mining, mineral and coal}

\section{INTRODUCTION}

Post-independence Indonesia on August 17, 1945, mining law was still using the product of the Dutch relics. The IndischeMijnwetwas made by making some changes and additions that are adjusted to the period of independence of the Indonesian nation. Indonesian government, in the era of the old Order, it used IndischeMijnwet until 1959. This was marked with the enactment of Law No. 10 of 1959 on Cancellation of Mining Rights. As for the consideration of the law, it was argued that in the presence of the private sector which had been spread in almost all of Indonesia by IndischeMijnwet. The private sector was granted mining authority. In order not to impede other parties to obtain mining rights, including the Government and the Regions, this law was enacted in a timely manner in order to promote national development.

Then in order to prepare for the new mining law, in 1960 the Government Regulation in Lieu of Law (PERPU) No. 37 of 1960 on Mining was enacted. It is the legal basis of Government Regulation In lieu of this law that the material of excavation in all areas of national sovereignty is used for the greatest prosperity of the people either in mutual assistance or individually. In addition, excavation materials have important meaning as an element for the development of various fields of industrial branch and as the necessary materials. This PERPU (Regulations) was formed to replace IndischeMijnwet because it cannot be used as a basis to achieve the ideals of the Indonesian nation and the development of national interest in depth in terms of political, social and strategic economy.

Related to Minerals and Coal (Minerba) contained in the territory of Indonesia, mining is one of the non-renewable natural resources as a gift of God Almighty. During this time, mineral and coal have an important role in fulfilling the livelihood of the people. Therefore, the management must be controlled by the State, in order to give real added value to the national economy as an effort to achieve prosperity and prosperity of the people fairly. Given the importance of the management of mineral and coal mining, the state should through its laws and regulations provide legal certainty to the management of mineral and coal mining in order to realize mining business activities in a useful, efficient and competitive manner. In addition, arrangements relating to the management of mineral and coal mining shall ensure legal certainty in the conduct of business activities, both from the mining licensing aspect to the aspects of impact analysis on the mining area environment.

Central government, provincial and regency/municipal areas through Law No. 4 of 2009 on Mineral and Coal Mining regulating the granting of mining business licenses. However, this changed when the issuance of Law No. 23 of 2014 on Regional Government in lieu of Law 32 Year 2004. This new rule provides that the district/city government has no right to issue a mining business permit because the authority is switched to provincial and central government. This writing will describe the facts and juridical studies on how the impact of changes in authority to grant mining business permits relate to the government's ranks both in the central, provincial and district/city.

\section{LEGAL POLICY IN THE FIELD OF MiNING}

Mining law has a very close relationship with environmental law as every mining, especially mineral and coal mining is required to maintain the sustainability of environmental carrying capacity[1][2]. It is intended to ensure that the preservation of environmental functions can be maintained for the benefit of future generations as defined in Article 1 number 5 of Law No. 4 of 2009 on Mineral and Coal Mining (Law No. 4 Year 2009). It then stipulates that every company engaged in mineral and coal mining is obliged to do the following:

1. The Company is required to have an Environmental Impact Analysis (AMDAL) (vide Article 15 Paragraph (1)). 
2. Conducting waste management of business results and/or activities (Article 16).

3. Conducting the management of hazardous and toxic substances (B3) (Article 17).

If the person or legal entity intentionally and/or neglect to pollute and damage the environment even impact on human will be penalized, both sanctions Sustainable development contains the meaning of quality assurance of human life and does not go beyond the ability of ecosystem to support it. In the Earth Summit at Rio Janiero, the five main principles in sustainable development are:

1. Intergenerational Justice (Inter-generational Equity).

2. Justice in one generation (Intra-generational Equity).

3. The principle of early prevention (Precautionary principle).

4. Biodiversity Protection (Conservation of Biological Diversity).

\section{Internalization of environmental costs.}

Sustainable development is not easy to implement because there are three main requirements: economic (inclusion of environmental costs), ecological aspects (limitation of natural resource use) and socio-cultural aspects (culture for maintenance of a project generally not yet in Indonesia)[3][2]. In the environmental ethics, sustainable development more closely follows the view of eco-centrism rather than anthropocentrism view. This principle of sustainable development that needs to be applied in mining law is of major concern to local governments in managing mining in their regions. However, the principle of decentralization adopted in Law No. 4 of the Republic of Indonesia (UU Minerba) as a step forward, although there are still many challenges In general. The aspect of the division of authority between government (central and regional) referring to the 1945 Constitution and the Law on Regional Government (UU No.12 of 2008) preparation of Law No. 4 of 2009, the essence is contained in Law no. 4 year 2009 outlines the exclusive authority of the government (central) and local governments in terms of: Determination of national policy; Legislation-making; Establishment of standards, guidelines and criteria; Establishment of national mineral mining ministry system; and Determination of mining areas after consultation with Local Government and House of Representative (DPR). The authority of the regional government in general is Mineral and Coal Mining Management activities regulated in the Regional Regulation, especially on the Procedure of granting Permits to the mining business.

In relation to the Environment, the Indonesian government has also made several policies in direct contact with the management of mining. Therefore, given the complexity of environmental management, the full authority to regulate the use and designation and legal relations in the mining field is done by the State through the government authorizes State-Owned Enterprises (SOE/S) to manage the mining business in the form of licensing. Mining and the environment have a close relationship with each other. It is seen that a mining business must meet the requirements on Environmental Impact Assessment (AMDAL) and environmental quality standards so that the mining business is really concerned about the environmental aspects. Because of the granting of authority to the local government, in the mining and the environment, the Regional Government should regulate and manage the mining business. Furthermore, it also needs to prioritize environmental factors and sustainable development or more precisely to create an environmentally sound mining business. Thereby, reducing the impact of mining efforts on the environment is deemed needed. To realize this goal, it needs to be supported by increased supervision or control of the government against mining business actors.

In this case the Government as a representation of the state, both central and regional have involvement in the management of natural resources results, including in the mining results that is in terms of regulation, management and supervision. Regarding the management of mineral resources, the derivation of Article 33 of the 1945 Constitution is Law No. 4 of 2009 on Mineral and Coal Mining. This is clarified in Article 4 paragraph (1) which reads:

"Minerals and coal as non-renewable resources are national assets that are controlled by the state for the greatest prosperity of the people."

Further in Article (2) it is stated that:

"The control of minerals and coal by the state as referred to in paragraph (1) shall be carried out by the Government and/or regional government."

Law No. 4 of 2009 on Mineral and Coal Mining regulates the issue of Mining Business License (IUP) in Mining Permit Areas (WIUP) which abolishes the provisions of Contract of Work Agreement contained in Law Number 11 of 1967 on the Principles Mining.

In connection with the process of mineral and coal mining business permit, in the government system has been arranged the division of authority between the Central Government, Provincial Government, and District/City Government. Article 6 to Article 8 of Law Number 4 Year 2009 states that the granting of Mining Business License (IUP) of rock based on Government Regulation No 23/2010 concerning Implementation of Mineral and Coal Mining Business Activity shall be conducted by means of regional application. The application of the territory means that any business enterprise, cooperative or individual who wishes to have an IUP must submit a request to the Minister, governor or regent of the mayor in accordance with his / her authority. The divisions of authority of the Minister, governor and regent / mayor are:

a. Minister of ESDM, for requests of territories that cross provincial or marine territory more than 12 miles from the coastline

b. Governor, for requests of territories within the territory of the regency/municipality within 1 province or sea territory 4 to 12 miles

c. Regent/mayor, for applications of territory within 1 regency/municipality or sea territory up to 4 miles.

However, based on Law Number 23 Year 2014 on Regional Government (in lieu of Law 32 Year 2004) has brought many changes in governance. One of them is the distribution of regional government affairs. Based on Article 9 of Law Number 23 Year 2014, the classification of government affairs consists of three affairs namely the absolute government affairs, the affairs of the concurrent 
government, and general government affairs. The absolute governmental affairs are Government Affairs fully become the authority of the Central Government. Concurrent government affairs are Government Affairs divided between Central Government and Provincial Region and District/city Region. General government affairs are Government Affairs which is the authority of the President as head of government. Regarding its relation to energy and mineral resources, the field becomes a matter of concurrent government of choice divided between the Central Government and Provincial Region and regency/municipality Region. In contrast to the previous law, the processing of mining business licenses owned by the district/municipal governments has become the authority of the provincial and central government.

\section{A. New Mining Policy}

On Wednesday January 11, 2017 President of the Republic of Indonesia Mr. JokoWidodo had signed Government Regulation No. 1 of 2017 on the Fourth Amendment of Government Regulation No. 23 of 2010 on the Implementation of Mining and Coal Mining Business Activities (PP No. 1 Year 2017). Indeed, this rule greatly affects many mineral and coal companies, including PT Freeport, and other coal and mineral issuers on the exchange. There is a provision on capital divestment of at least $41 \%$, which was previously $20 \%$. Then there are the new provisions of nickel and bauxite levels that can be exported. Important points contained in PP no. 1 Year 2017 are:

a. Changes in the period of application for renewal of Mining Business License/Mining Business License (IUP / IUPK) not later than 5 (five) years prior to the end of the business license period;

b. Changes in provisions on the divestment of shares up to $51 \%$ in stages;

c. Arrangements on benchmark pricing for mineral and coal sales;

d. Elimination of provisions that holders of the Contract of Work (COW) that have purified can perform the sale of processing results in a certain amount and time; and

e. Further regulation related to the implementation procedure Increase of added value and sales of metal minerals will be further regulated by Ministerial Regulation.

Another policy is the Regulation of the Minister of Energy and Mineral Resources (Permen ESDM No. 5 Year 2017) on Increasing Mineral Added Value through Mineral Processing and Purification Activities in the Country, namely:

a. Holders of Production Operation Mining Licenses (IUPOP), Special Operating License of Production Operations (IUPK-OP), Mining Production Operation License (IUPP), special processing and/or purification shall perform processing and refining of mining products according to the minimum processing limit and/or purification.

b. Implementation of processing and purification of mining results can be done alone or cooperate.

c. Low grade nickel below $1.7 \%$ and low grade bauxite below $42 \%$ shall be absorbed by a minimum refining facility of $30 \%$ of the smelter input capacity.

d. If domestic demand for low grade nickel and low grade bauxite has been fulfilled and there is still an unabsorbed supply, the remaining nickel ore and low grade bauxite can be sold overseas.

e. Metal KK Holder holders may only conduct the sale of purification products abroad after meeting the minimum refining limits.

In order to encourage the implementation of the downstream project, the Government provides the opportunity to hold Metal Work Contract (KK) Minerals, Production Operations Mining Permit (IUP-OP), Production Operation Mining Special License (IUPK-OP), Production Operation Mining License (IUP- OP) for processing and/or purification, and others to sell overseas concentrate for the next 5 years since the issuance of Regulation of the Minister of Energy and Mineral Resources No. 6 of 2017 on Procedures and Requirements for the Implementation of the Implementation of Sales of Minerals Overseas Results Processing and Purification (Permen ESDM No. 6 Year 2017), with condition, as follows:

a. change KK to IUPK Production Operation

b. giving smelter development commitment

c. Pay the maximum $10 \%$ export duties in accordance with physical progress and financial realization of smelter development.

d. Overseas sales can only be made after obtaining export approval recommendation from the Director General on behalf of the Minister.

Subsequently, in the case of Recommendation Application by IUPK holder of Metal Mineral Production Operation, Metal Mineral Production Operation IUP, and Production Operation IUP specifically for processing and/or purification must be equipped with the following requirements:

a. Integrity pacts to undertake the construction of domestic refining facilities as contained in Attachment II which is an integral part of Ministerial Regulation No. EMR. $6 / 2017$

b. Copy of Clear and Clean $(\mathrm{CnC})$ certificate for Metal Production Operation IUP holder;

c. Report of Analysis (RoA) or Certificate of Analysis (CoA) of Metallic Minerals products that have met the minimum limit of Processing issued 1 (one) last month from independent surveyors appointed by the Minister;

d. Certificate of payment of Non Tax State Revenue payment for the last 1 (one) year issued by the Directorate General of Mineral and Coal;

e. Plans for the construction of domestic refining facilities verified by Independent Verifiers, among others, the construction schedule of refining facilities, investment value, and input capacity per year;

f. The work plan and budget of the current year which have been approved by the Minister or the governor in accordance with their authority;

g. Report on the result of verification of physical progress from Independent Verifier for IUPK Holders of Metal Mineral Production Operation, Metal Mineral Production Operation IUP, and Production Operation IUP specifically for processing and/or purification that have been or are conducting the development of Purification facility;

For overseas sales plans are required to include, among others, the types and quantities of Metal Minerals that have met the minimum limit of Processing/nickel with a level of 
$<1.7 \%$, bauxite washed bauxite with $\mathrm{Al} 2 \mathrm{O} 3>42 \%$ Tariff / HS (Harmonized System), port of loading, unloading port, and destination country, and so forth.

\section{B. Governor Has Authority To Revoke Unclear IUP}

One of the duties of Provincial government throughout Indonesia is to complete the regulation on mining business permit (IUP) which is still a Non-Clear and Clean $(\mathrm{CnC})$ status. Moreover, the regulation is mandated by the Minister of Energy and Mineral Resources Regulation No. 43 of 2015 on Procedures for the Evaluation of Mining IUP of Mining issued based on Coordination and Supervision recommendations in minerals and coal (minerba) sector conducted by Corruption Eradication Commission (KPK). Based on data owned by Ombudsmen RI, there are no less than 4,000 non-CnC IUPs that have not been disciplined throughout Indonesia. In addition, 6.3 million hectares of mining permits remain in 1.37 million hectares of Conservation Forest and 4.93 million hectares of Protected Forest, while Law 41 of 1999 on Forestry states that both areas should be free from the mining industry. Researcher of PWYP Indonesia Economic Policy, WikoSaputra in Jakarta Tuesday, 10/5/2017 ago said that there are still arrears by IUP, KK and PKP2B company, there are around Rp25 trillion of bad debts from PNBP sector. As many as $75 \%$ of IUPs do not pay reclamation and post-mining guarantees, and there were 1087 NPWP IUP have not been identified. A number of recommendations from the KPK have been delegated to stakeholders in the Mineral and coal mining sector at both the National and Local Governments level. The recommendations include the evaluation of the implementation of minerals in areas that have become the authority of the Governor, after Law 23 of 2014 on Regional Government. The Ministry of Energy and Mineral Resources has followed up by issuing ESDM Regulation No. 43 of 2015 on Procedures for Evaluating the Issuance of Mining and Mineral Mining Business Licenses. It regulates the evaluation of IUP issuance based on five criteria including administration, regional, technical, environment and financial. Stipulation of deadline for submission of evaluation result of issuance of IUP by governor up to 90 working days since the issuance of the candy at the end of December 2015 and ending around mid of May 2016. Including IUP recommended by $\mathrm{CnC}$ prior to enactment of ESDM Ministerial Regulation No. 43 Year 2015. Mining Corset aims to identify problems and reform the management of the mineral and coal mining sector in Indonesia. In its implementation over the past three years, the KPK (Corruption Eradication Commission) has focused on five main issues: the arrangement of IUP, the implementation of financial obligations, supervision of mining production, sales supervision, shipment of mining products and the processing or purification of mining products. KorsupMinerba covers 31 provinces all over Indonesia. The findings and recommendations in the mineral and coal mining sectorCorridor above must continue to be guarded by civil society so that its implementation can improve the chaotic management of mineral and coal mining sector completely.

\section{CONCLUSION AND SUGGESTIONS}

\section{A. Conclusion}

Based on the above description, the researcher has described in the previous chapters, it can be concluded as follows:

1. The Mining Policy of each Government of Indonesia regime shall be the background for the change of authority to grant mining permits from the district/municipality governments to the provincial and central government, such as:

a. Internal aspect, the change of authority is based on the number of irregularities committed by regency/municipal governments both from political and legal elements.

b. Externally, this change of authority is also influenced by the interests of investors who will invest in the mining sector. Investors want to create legal certainty and investment certainty in the implementation of mining business. This change of authority is expected to make the mining licensing process more systematic and efficient.

2. The juridical impact of a change in the authority to grant a mining business license is not in accordance with the law enforcement regulations, the issuance of a circular letter, both the minister of ESDM and the minister of home affairs, containing the implementation of government affairs after the enactment of Law No. 23 of 2014 is a necessity. The circular affirms that the district/city government is still obliged to assist the provincial and central government to coordinate the granting of mining permits even when the authority has been transferred. The authority of the district/city government is based on Co-Administration provided by the provincial or central government. Nevertheless, the circular letter cannot be a strong basis for the implementation of the regulation, the government still has to issue an implementing regulation to manage the distribution of government affairs clearly.

\section{B. Suggestions}

As concrete actions that need to be done by the government in the field of mining are suggested as follows:

1. The Government shall immediately regulate all permits (IUP and PKP2B / KK) that enter into conservation and protection forest areas.

2. Provincial Government through Information and Documentation Management Officer (PPID) must open access to information related to mining data as mandated by Law No.14 year 2008 on Public Information Transparency

3. The Governor of each Province to immediately follow up the ESDM Regulation no. 43 of 2015 to revoke non-C \& C IUP.

4. Minister of Energy and Mineral Resources to use the authority pursuant to Article 152 of Law No. 4 Year 2009 in cracking down on IUP problem.

5. The Government shall immediately collect all unpaid corporate financial liabilities in the PNBP sector. 


\section{REFERENCES}

[1] M. A. Santosa, Aktualisasi Prinsip-Prinsip Pembangunan Berkelanjutan Yang Berwawasan Lingkungan Dalam Sistem Dan Praktek Nasional. 1996.
[2] A. Hidayat and F. A. Samekto, Hukum Lingkungan Dalam Perspektif Global Dan Nasional. Semarang: Undip, 1998.

[3] O. Soemarwoto, Indonesia Dalam Kancah Isu Lingkungan Global. Jakarta: Gramedia PustakaUtama, 1991. 